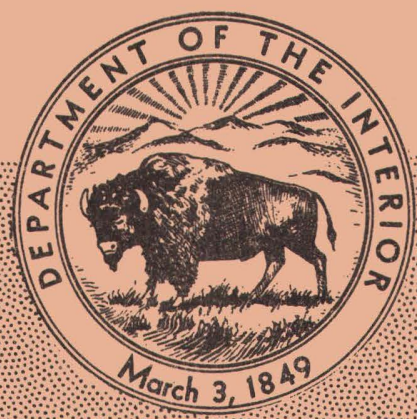

\title{
VIRGIN VALLEY OPAL DISTRICT HUMBOLDT COUNTY, NEVADA
}

By M. H. Staatz and H. L. Bauer, Jr.

This report concerns work done on behalf of the U. S. Atomic Energy Commission and is published with the permission of the Commission. 
UNITED STATES DEPARTMENT OF THE INTERIOR Oscar L. Chapman, Secretary

GEOLOGICAL SURVEY

W. E. Wrather, Director

GEOLOGICAL SURVEY CIRCULAR 142

\section{VIRGIN VALLEY OPAL DISTRICT, HUMBOLDT COUNTY, NEVADA}

M. H. Staatz and H. L. Bauer, Jr. 


\title{
VIRGIN VALLEY OPAL DISTRICT, HUMBOLDT COUNTY, NEVADA
}

\author{
CONTENTS
}

Fage

Page

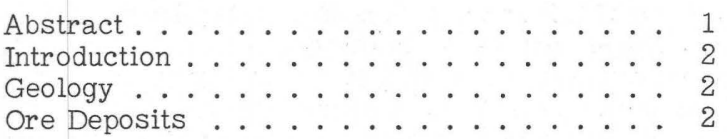

Ore Deposits-Continued

Form of deposits......... 2

Radioactivity ......... 5

Suggestions for Prospecting . . . . . . 7

\section{ILLUSTRATIONS}

Figure 1. Index map, Virgin Valley, Humboldt County, Nevada . . . . . . . . . . . . 4

2. Geologic map and section, east side of Virgin Valley, Humboldt County, Nevada. . . . . . . 6

3. Geologic map and sections, west side of Virgin Valley, Humboldt County, Nevada. . . . . . 3

\section{ABSTRACT}

The Virgin Valley opal district, Humboldt County, Nevada, is near the Oregon-Nevada border in the Sheldon Game Refuge. Nineteen claims owned by Jack and Toni Crane were examined, sampled, and tested radiometrically for uranium.

Numerous discontinuous lavers of opal are interbedded with a gently-dipping series of vitric tuff and ash which is at least $300^{\circ} \mathrm{ft}$ thick. The tuff and ash are capped by a dark, vesicular basalt in the eastern part of the area and by a thin layer of terrace gravels in the area along the west side of Virgin Valley.

Silicification of the ash and tuff has produced a rock that ranges from partly opalized rock that resembles silicified shale to completely altered rock that is entirely translucent, and consists of massive, brown and pale-green opal.

Carnotite, the only identified uranium mineral, occurs as fracture coatings or fine layers in the opal; in places, no uranium minerals are visible in the radioactive opal.

The opal layers are irregular in extent and thickness. The exposed length of the layers ranges from 8 to 1,200 ft or more, and the thickness of the layers ranges from 0.1 to $3.9 \mathrm{ft}$.

The uranium content of each opal layer, and of different parts of the same layer, differs widely. On the east side of Virgin Valley four of the seven observed opal layers, nos. 3, 4, 5, and 7, are more radioactive than the average; and the uranium content ranges from 0.002 to 0.12 percent. Two samples, taken $5 \mathrm{ft}$ apart across opal layer no. 7, contained 0.003 and 0.049 percent uranium. On the west side of the valley only four of the fifteen observed opal layers, nos. 9, 10, 14, and 15, are more radioactive than the average; and the uranium content ranges from 0.004 to 0.047 percent. Material of the highest grade was found in a small discontinuous layer of palegreen opal (no. 4) on the east side of Virgin Valley. The grade of this layer ranged from 0.027 to 0.12 percent uranium. 


\section{INTRCDUCTION}

Uraniferous opal has been found in the Virgin Valley opal district, Humboldt County, Nev. (fig. 1). This district has produced some of the best gem opal found in the United States. The district is on the Virgin Valley ranch in T. 45 N. , R. 26 E., Mt. Diablo principal meridian, in the Sheldon Game Refuge, 88 miles east of Cedarville, Calif., and 41 miles west of Denio, Nev. Denio, Nev., is on the OregonNevada boundary line and is 102 miles northwest of Winnemucca, Nev. A road log from the post office in Denio to the Virgin Valley Ranch house is given below.

\section{Road log}

\begin{tabular}{|c|c|}
\hline Mileage & Description \\
\hline 0.0 & $\begin{array}{l}\text { Fost office, Denio - travel west on } \\
\text { State Route } 8-A \text {. }\end{array}$ \\
\hline 2.7 & Junction - keep to the left. \\
\hline 4. 3 & Junction - keep to the left. \\
\hline 5.1 & Junction - keep to the right. \\
\hline 11.4 & Junction - keep to the right. \\
\hline 14.4 & Junction - keep to the left. \\
\hline 15.5 & Enter Sheldon Game Refuge. \\
\hline 30.7 & $\begin{array}{l}\text { Junction - turn left on the Camp } \\
\text { Sheldon road. }\end{array}$ \\
\hline 30.9 & Junction - keep to the left. \\
\hline 31.9 & Junction - keep to the right. \\
\hline 33.2 & Camp Sheldon (Old CCC Camp). \\
\hline 33.3 & Junction - turn to the right. \\
\hline 36.4 & Gate in fence. \\
\hline 37.8 & Small reservoir. \\
\hline 41. 4 & $\begin{array}{l}\text { Virgin Valley ranch house. Workings } \\
\text { are } 200 \text { yards nor thwest and } 300 \\
\text { yards northeast of the ranch house. }\end{array}$ \\
\hline
\end{tabular}

The area examined consists of 19 claims located by Jack and Toni Crane of Route 2, Oswego, Oreg. , during July and August 1950. These claims are: the Monday, Tuesday, Wednesday, Thursday, Friday, Saturday, and Wee Wee Marie--all on the west side of Virgin Valley; and the September, October, March, 4th of July no. 1, 4th of July no. 2, February, April Fool no. 1, April Fool no. 2, January, November, August, and December--on the east side of the valley. Before the discovery of uranium minerals in 1950 about 20 small pits had been dug on the east side of Virgin Valley during prospecting for semiprecious opal. Several thousand pounds of a light green fluorescent opal and a mottled, variegated opal have been mined and sold to mineral collectors and cabochon cutters. Uranium minerals were discovered by Jack Crane early in the summer of 1950. Development work done since that time consists of a 315-foot bulldozer trench and 12 small pits on the east side of the valley, and 3 small pits on the west side of the valley.

The properties were examined on behalf of the Atomic Energy Commission by M. H. Staatz and H. L. Bauer, Jr., of the U. S. Geological Survey from November 4 th to 7 th, 1950. An area of 1,000 by $1,200 \mathrm{ft}$ on the east. side of Virgin Valley (fig. 2), and an area of 750 by $1,580 \mathrm{ft}$ on the west side of Virgin Valley (fig. 3) were mapped with a plane table and a telescopic alidade on a scale of 1:1200. Two grab samples and 35 channel samples were analyzed for uranium. All opal beds in the mapped area were tested radiometrically along their outcrop with a Geiger-Mueller counter (Victoreen).

Jack Crane guided the party around the property and gave much valuable information on the area.

\section{GECLOGY}

The Virgin Valley has been cut in a series of gently-dipping tuff and ash beds capped by a basalt flow and terrace gravels. The intimately interbedded series of tuff and ash beds is at least $300 \mathrm{ft}$. thick. Individual beds range in thickness from 0.1 to $10 \mathrm{ft}$; most of them are from 1 to 3 st in thickness. Greenishgray, vitric tuff beds are most common, and consist largely of fragments between 0.5 and 30 millimeters in diameter. The tuff is porous and quite friable. In general the ash beds are lighter colored than the tuffs; many are white. Numerous extremely fine-grained, chalk-white ash beds occur on the east.side of Virgin Valley. These beds, which range in thickness from 0.1 to $4 \mathrm{ft}$ and consist in part of clay minerals, are probably altered feldspathic tuffs.

Basalt caps the hilltops on the east side of Virgin Valley about 400 yards east of, and 200 feet above, the mapped area. Along the west side of Virgin Valley, the ridges in the mapped area are capped by a thin layer of terrace gravels, containing pebbles of volcanic rocks and fragments of fossilized wood, opal, and chert. The valley floor is covered with alluvium.

\section{ORE DEPOSITS}

The uraniferous opal occurs in discontinuous layers parallel to the bedding of the ash and tuff beds. The opal is confined to tuff beds in most places, but on the east side of Virgin Valley some of the opal layers, especially the more translucent varieties, occur in fine-grained, chalk-white ash beds. In the area mapped on the east side of Virgin Valley (fig. 2), four of seven opal layers were more radioactive than average. In the area mapped on the west side of the valley (fig. 3), four of fifteen opal layers were more radioactive than average.

\section{Form of Deposits}

The only uranium mineral noted is a fine, powdery, canary-yellow mineral, which has been identified as carnotite. It commonly occurs as fine coatings on parting planes and fractures. In one place, the carnotite occurs as fine yellow layers, and appears to have been deposited simultaneously with opal. In some opal layers, no uranium minerals are visible, but analyses indicate a uranium content higher than average. An example of this is the pale-green opal on the east side of Virgin Valley, in which the uranium either is an integral part of the opal or is present as finely scattered, minute grains of carnotite.

Hydrated silica is common in tuff and ash beds of the district, and many stages of silicification were noted. Where relatively small amounts of silica have been added the silicified rock resembles a silicified shale bed, and all the original pyroclastic structure 


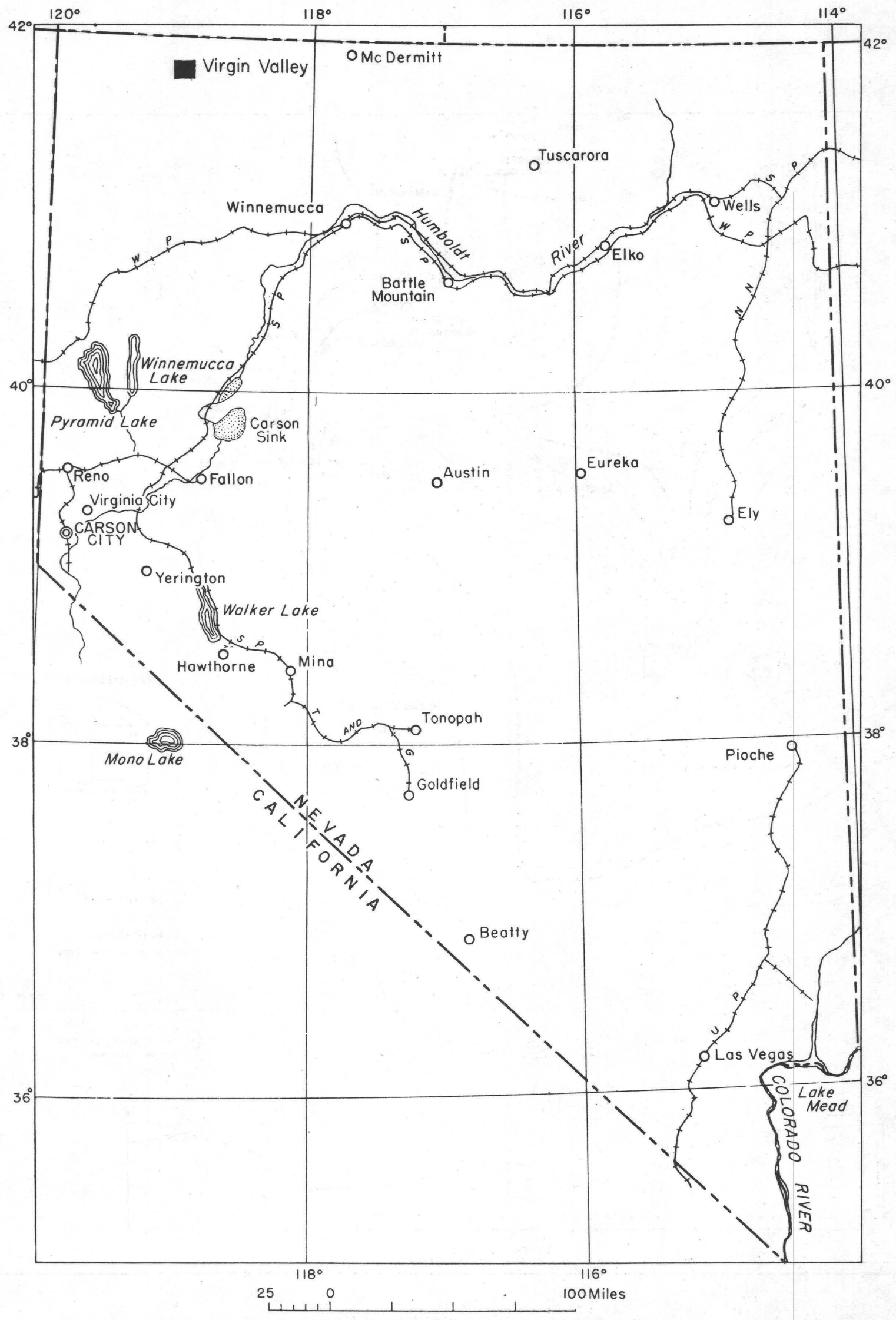

Figure 1. --Index map, Virgin Valley, Humboldt County, Nevada 


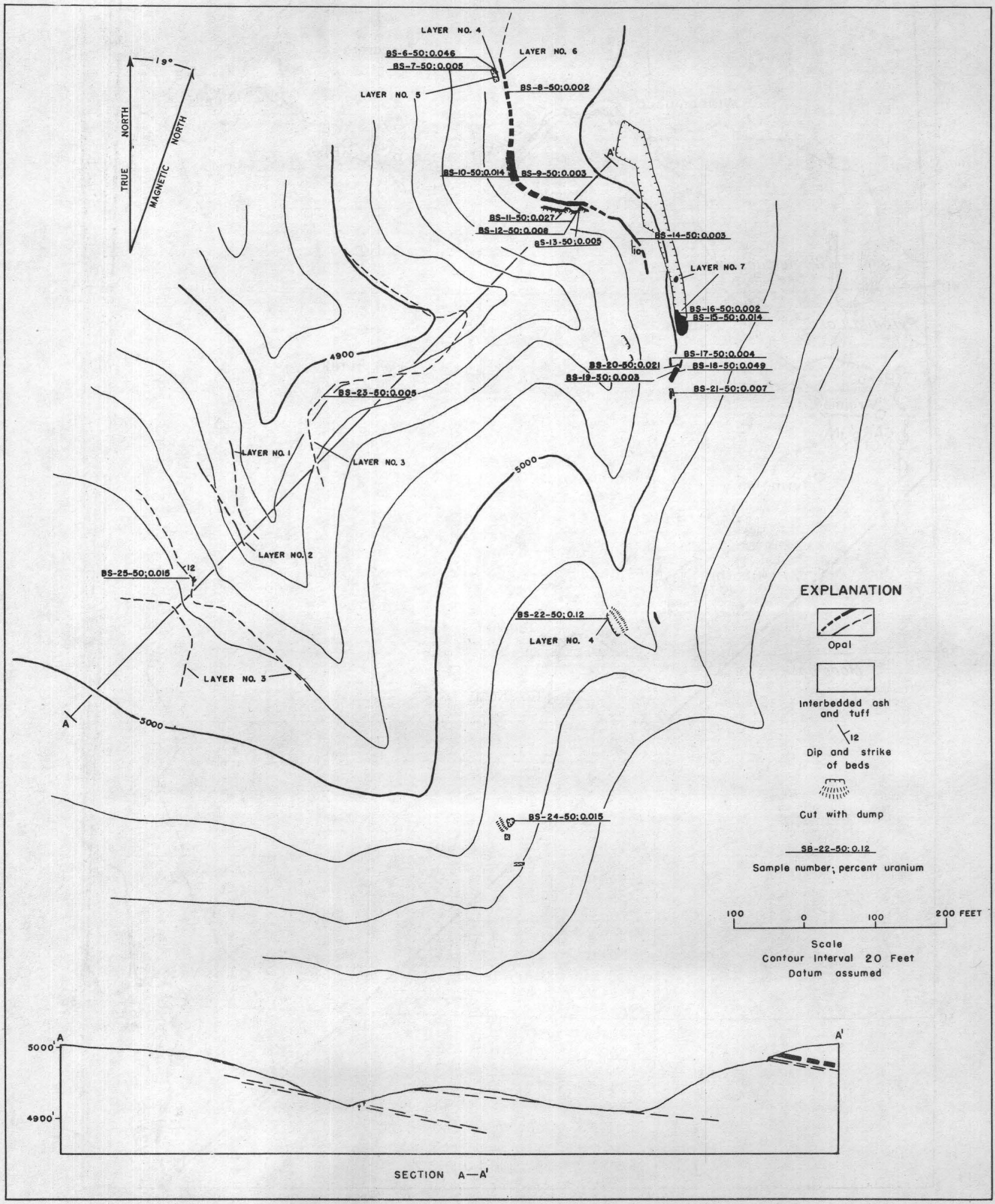

Figure 2. --Geologic map and section, east side of Virgin Valley, Humboldt County, Nevada 
has been destroyed. Thoroughly opalized layers are translucent. The opal in the mapped area has a distinctive conchoidal fracture and is gray, brown, tan, black, white, and pale green. Some of the opal is banded, some is uniform in color, and some is variegated. Banding is usually parallel to the bedding in the tuff and ash beds. Hair-line fracturing or "checking" is common, especially in some of the less opalized layers.

The uraniferous opal layers differ considerably in length and thickness. Two layers (no. 10 and no. 12) on the west side of Virgin Valley (fig. 3) were followed continuously for more than $1,200 \mathrm{ft}$ along strike; others are much shorter--such as a variegated opal layer on the east side of the valley, which is only $8 \mathrm{ft}$ long. The layers mapped were from 0.1 to $3.9 \mathrm{ft}$ thick.

\section{Radioactivity}

The radioactivity of all opal layers was checked at numerous points along their strike with a GeigerMueller counter. Readings on the counter ranged from two divisions on the 0.2 scale to seven divisions on the 2. 0 scale. Nineteen samples were taken of the opal on the east side of Virgin Valley, 16 samples were taken of opal on the west side, and 2 samples were taken of white ash adjacent to opal beds (tables 1 and 2).

Table 1. --Analyses of samples, east side of Virgin Valley, Nev.

\begin{tabular}{c|c|l|c|c}
\hline $\begin{array}{c}\text { Field sample } \\
\text { number }\end{array}$ & $\begin{array}{c}\text { Layer } \\
\text { number }\end{array}$ & \multicolumn{1}{|c|}{ Description } & $\begin{array}{c}\text { Equivalent } \\
\text { uranium } \\
\text { (percent) }\end{array}$ & $\begin{array}{r}\text { Uranium } \\
\text { (percent) }\end{array}$ \\
\hline BS- 6-50 & 4 & Pale-green opal & 0.048 & .046 \\
BS- 7-50 & 5 & Tan to brown opal & .004 & .005 \\
BS- 8-50 & 6 & White, iron-stained opal & .002 & .002 \\
BS-9-50 & 6 & White, iron-stained opal & .014 & .003 \\
BS-10-50 & 5 & Brown, variegated opal & .033 & .014 \\
BS-11-50 & 4 & Brown to pale-green opal & .010 & .027 \\
BS-12-50 & 5 & Brown, variegated opal & .003 & .008 \\
BS-13-50 & 6 & White, iron-stained opal & .001 & .005 \\
BS-14-50 & 6 & White, iron-stained opal & .019 & .003 \\
BS-15-50 & 7 & Gray, iron-stained opal & .003 & .002 \\
BS-16-50 & 7 & Gray, iron-stained opal & .049 & .004 \\
BS-17-50 & 6 & White, iron-stained opal & .002 & .049 \\
BS-18-50 & 7 & White to pale-green opal & .014 & .003 \\
BS-19-50 & 7 & Brown opal & .003 & .021 \\
BS-20-50 & 7 & Brown to tan opal & .11 & .007 \\
BS-21-50 & - & Chalk-white ash & .005 & .12 \\
BS-22-50 & 4 & Pale-green opal & .013 & .005 \\
BS-23-50 & 3 & Yellowish to brown opal & .014 & .015 \\
BS-24-50 & - & White to black, variegated opal & .015 \\
BS-25-50 & 3 & Tan to greenish-brown opal & & \\
\hline
\end{tabular}

Table 2. --Analyses of samples, west side of Virgin Valley, Nev.

\begin{tabular}{|c|c|c|c|c|}
\hline $\begin{array}{c}\text { Field Sample } \\
\text { number }\end{array}$ & $\begin{array}{l}\text { Layer } \\
\text { number }\end{array}$ & Description & $\begin{array}{c}\text { Equivalent } \\
\text { uranium } \\
\text { (percent) }\end{array}$ & $\begin{array}{l}\text { Uranium } \\
\text { (percent) }\end{array}$ \\
\hline$B S-26-50$ & 12 & Cream to $\tan$ opal & 0.002 & 0.002 \\
\hline $\mathrm{BS}-27-50$ & 10 & Brown to white opal & .015 & .019 \\
\hline$B S-28-50$ & 12 & Cream to tan opal & .003 & .003 \\
\hline BS-29-50 & 10 & Brown to gray, banded opal & .016 & .021 \\
\hline $\mathrm{BS}-30-50$ & 10 & Brown, banded opal & .021 & .018 \\
\hline BS $-31-50$ & 12 & White to brown opal & .002 & .003 \\
\hline BS $-32-50$ & 9 & Gray to brown, variegated opal & .004 & .007 \\
\hline $\mathrm{BS}-33-50^{\circ}$ & 10 & Gray, variegated opal & .024 & .033 \\
\hline$B S-34-50$ & 9 & Tan to brown opal & .032 & .047 \\
\hline BS $-35-50$ & 10 & Tan to brown opal & .040 & .038 \\
\hline BS-36-50 & 14,15 & $\begin{array}{l}\text { Two tan to brown opal layers } \\
\text { separated by ash bed }\end{array}$ & .026 & .032 \\
\hline BS-37-50 & -- & Gray ash & .007 & .003 \\
\hline BS $-38-50$ & 14,15 & $\begin{array}{l}\text { Two tan to brown opal layers } \\
\text { separated by ash bed }\end{array}$ & .018 & .024 \\
\hline BS $-39-50$ & 10 & Gray, iron-stained opal & .020 & .025 \\
\hline $\mathrm{BS}-40-50$ & 9 & Brown, variegated opal & .004 & .004 \\
\hline$B S-41-50$ & 10 & $\begin{array}{l}\text { White to brown, variegated } \\
\text { opal }\end{array}$ & .025 & .030 \\
\hline$B S-42-50$ & 9 & Gray, iron-stained opal & .004 & .005 \\
\hline
\end{tabular}




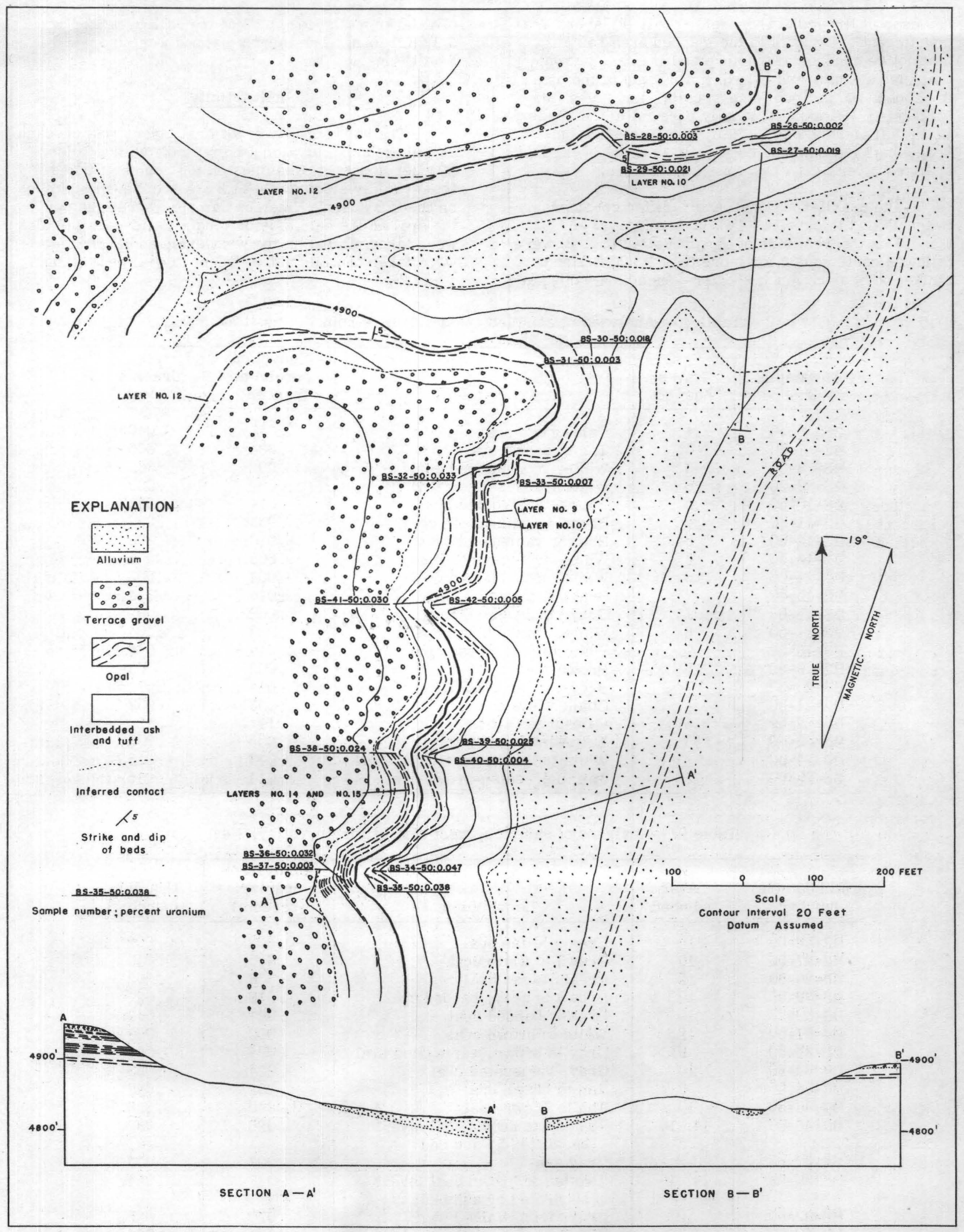

Figure 3. --Geologic map and sections, west side of Virgin Valley, Humboldt County, Nevada 
The radioactivity and uranium content of the opal differ in individual layers and along the same layer. Layer no. 7 on the east side of Virgin Valley demonstrates the range of uranium content of a single layer. Near the center of the eastern edge of the area (fig. 2) white to pale-green opal is exposed on the east side of a small, 5-foot-wide pit, and brown opal is exposed on the west side. The uranium content of the white to pale-green opal is 0.049 percent; the uranium content of the brown opal is 0.003 percent.

The uranium content of opal ranges from 0.002 to 0.12 percent (tables 1 and 2). Of the 15 opal layers on the west side, nos. 9, 10, 14, and 15 showed higher radioactivity than the average. The uranium content of layer no. 9 ranged from 0.004 to 0.047 percent in four samples, but only one sample contained over 0.007 percent. Seven samples, taken over an outcrop length of 1,220 feet in layer no. 10 ranged from 0.018 to 0.038 percent uranium. This layer averages 1 foot in thickness. Layers no. 14 and no. 15 are about half a foot thick and are separated by a thin layer of ash. These two opal layers and the intervening ash bed were sampled together, and two samples showed 0.024 to 0.032 percent uranium. These layers are exposed for about $400 \mathrm{ft}$ along strike.

Of the seven layers on the east side of Virgin Valley, nos. 3, 4, 5, and 7 showed higher radioactivity than average. Layer no. 3 is exposed over an outcrop length of $400 \mathrm{ft}$ in the western half of the mapped area (fig. 2). Two samples of this layer contained 0.005 and 0.015 percent uranium respectively.

Layer no. 4 is made up of a series of small discontinuous lenses, 12 to $25 \mathrm{ft}$ in outcrop length, in a chalk-white ash bed. It is $2 \mathrm{ft}$ or more in thickness, and the pale-green opal has a uranium content of 0.027 to 0.12 percent. The uranium content of this pale-green opal is the highest in the district. About 300 feet southwest of the southern- most exposure of pale-green opal is a small lens of clear to translucent variegated opal. This lens may be on the same horizon as the pale-green opal, or it may be in a higher horizon. The clear to translucent variegated opal and the pale-green opal are sold to mineral collectors and cabochon cutters for $\$ 0.25$ or more per pound.

Layer no. 5 is separated by 1.5 to $2 \mathrm{ft}$ of tuff and ash beds from layer no. 4 and is from 0.5 to 1.0 foot in thickness. It is a variegated light-brown to black opal with a uranium content from 0.005 to 0.014 percent.

Layer no. 7 is exposed in the bulldozer trench and in several trenches near the top of the ridge. It is characterized by wide ranges of thickness, shape, color, and uranium content. It is 0.5 to 3.9 ft thick, and is commonly irregular, with many small stringers extending into the chalk-white ash from the main opal mass. Its color ranges from brown or gray to translucent white or pale green, and its uranium content ranges from 0.002 to 0.049 percent. In one of the pits this layer is encrusted by fine, powdery carnotite.

\section{SUGGESTIONS FOR PROSFECTING}

The uranium content of the known deposits of uraniferous opal in the Virgin Valley opal district is insufficient to warrant economic development at present prices. The possibilities of finding economically minable material by additional exploration of known uraniferous layers are not considered good.

Only a small area was studied in detail for this report. Because opal deposits are widely distributed in the Virgin Valley area, however, further prospecting may discover additional deposits of radioactive cpal. Frospecting should be directed toward the discovery of opal layers of greater thickness and regularity, and of higher uranium content than those described in this report. 